\title{
Model Accounting System for Panchayati Raj Institution and Its Outlook
}

\author{
Dr. Pushpendra Misra ${ }^{1}$, Anshu Gupta ${ }^{2}$ \\ ${ }^{1}$ Associate Professor, Department of Commerce, Dr. Shakuntala Misra National Rehabilitation University, Lucknow \\ ${ }^{2}$ Research Scholar( JRF), Department of Commerce, University of Lucknow, Lucknow
}

\begin{abstract}
Model Accounting System is introduced by C\&AG on the recommendation of Eleventh Finance Commission. Model Accounting System is based on the concept of Cash Book, The Accounts are to be kept in two parts, Part - I To record transactions of all receipts and expenditure relating to Panchayats Fund, Part - II To record transactions relating to Provident Funds, Loans, Deposits and Advances in this account are classified in four different head viz. Major Head, Minor Head, Sub-Head and Object Head
\end{abstract}

Keywords: Panchayati Raj Instituion, Model Accounting System, Cash Book

\section{Introduction}

As we know that every institution needs to keep account records so as Panchayati Raj Institutions (PRIs) are also required to maintain its income and expenditure records. So for which Model Accounting System was constituted by Technical Committee on Budget and Accounting Standard for PRIs, It was simply based on cash nature transaction with provision to shift accrual accounting. Model accounting system does gives accounting record of cash received or paid during financial year all transaction are recorded daily Cash Book. It does follow same accounting rule for the recording of the transactions. As per the recommendations of the Eleventh Finance Commission, the Ministry of Finance (MOF) had issued guidelines for Utilization of Grants to Local bodies in June 2001. "The Comptroller and Auditor General of India (C\&AG) shall be responsible for exercising proper control and supervision over the proper maintenance of accounts and their audit for all 3 tiers/levels of PRIs and Urban Local Bodies (ULBs)."( Para 6.4 of the Ministry of Finance) As of 30th April, 2009 out of 24 States where 73rd \& $74^{\text {th }}$ amendments are applicable, entrustment of TGS to CAG has been received in 22 states and one Union Territory. The Ministry of Panchayati Raj, Government of India after consultative process with C\&AG and State Governments prepared a Model Accounting System for the Panchayati Raj Institutions toensure transparency and accountability in the operations of the financial transactions in Panchayats

\section{Literature Review}

As there is not yet any publication related to Model

Accounting System is available all review work was base on published formats. Guidelines \& list of codes from Ministry of Panchayati Raj, Government of India

\section{Research Methodology}

The proposed research work is descriptive research and data based on published report of Ministry of Panchayati Raj, Government of India, all data are collected relevant source.
Objective of the Study

- To understand the Accounting System for Panchayati Raj Institution

- To explore the concept of Model Accounting system

Panchayati Raj Institutions (PRIs)

PRIs are constitute in Three Tier of the administrative set

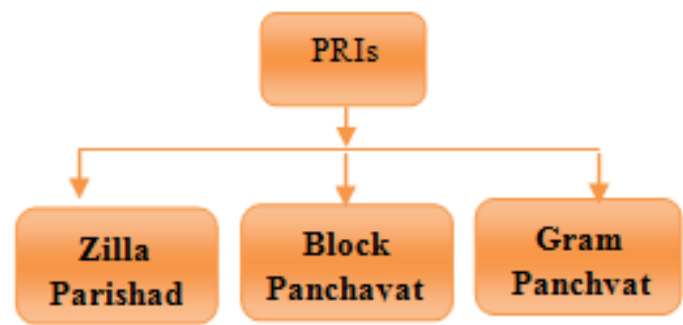

\section{Zilla Parishad}

Zilla Parishad is a local government body at the district level in India. It looks after the administration of the rural area of the district and its office is located at the district headquarters. Zilla Parishad has minimum of 50 and maximum of 75 members. Its sources of Income involve taxes onwater, pilgrimage, markets, etc. and fixed grant from the State Government in proportion with the land revenue and money for works and schemes assigned to the Parishad.

\section{Block Panchayat}

The block Panchayat is the local government, set at the block or tehsil level, for a group of gram panchayats in states where the total population exceeds 20 lakh.

\section{Gram Panchayat}

Gram panchayats are local governments at the village or small town level. A gram panchayat can be set up in villages with minimum population of 300 . Sometimes two or more villages are clubbed together to form group-gram panchayat when the population of the individual villages is less than 300. The main source of income of the Gram Panchayat is the property tax levied on the buildings and the open spaces 


\section{International Journal of Science and Research (IJSR) \\ ISSN (Online): 2319-7064}

Index Copernicus Value (2013): 6.14 | Impact Factor (2014): 5.611

within the village. Other sources of income include professional tax, taxes on pilgrimage, animal trade, grant received from the State Government in proportion of land revenue and the grants received from the Zilla Parishad.

\section{Model Accounting System}

The Ministry of Panchayati Raj, Government of India after consultative process with C\&AG and State Governments prepared a Model Accounting System for the Panchayati Raj Institutions to ensure transparency and accountability in the operations of the financial transactions in Panchayats. Basically Model Accounting is designed as cash book, in this all transaction of cash nature are recorded.

\section{Accounting Procedure for Model Accounting System}

The accounting practices prescribed for PRIs are by and large; akin to the accounting practices followed by the State Governments which are as follows.

- Each institution i.e. Zilla Parishad/Mandal Parishad / Gram Panchayat is an accounting entity.

- The accounts are kept on cash basis.

- The financial transactions are classified on three tier structure i.e. Functions (major head), programs/ schemes (minor head)and objects( object head)

- The nomenclature of the Major Heads is kept identical to the 29 functions listed in the Eleventh Schedule of the Constitution.

- Sub-heads have been prescribed for classification of scheme under appropriate function.

- States may choose and operate those major/minor heads as required in their particular context without changing the overall structure.
- There is a strong relationship between accounting and budgeting and the accounting system provides the basis for appropriate budgetary control.

- The institutions are not require-d to prepare a balance sheet and the details of assets are kept in the subsidiary registers and records of the PRI

- The Receipts and Payments Accounts would incorporate revenue and capital, deposits, loans and advances and remittances.

- Period of accounts is a financial year ending 31st March.

The Accounts are to be kept in two parts,

Part - I To record transactions of all receipts and expenditure relating to Panchayats Fund

Part - II To record transactions relating to Provident Funds, Loans, Deposits and Advances

\section{Salient Features of the Accounts (Classification)}

Account are classified according to Major Head, Minor Head and Object Head

- First tier i.e. Major Head (four-digit) represent functions enumerated in the Eleventh Schedule of the Constitution.

- Second tier i.e. Minor Head (three-digit) represent activity/programme of the functions.

- Third tier i.e. Object Head (two-digit) represent the object of receipts/ expenditure.

- A two digit sub-head is introduced to distinguish the grants released by central and state governments. Considering the number of state schemes Alpha-numeric sub-heads can be operated for state schemes.

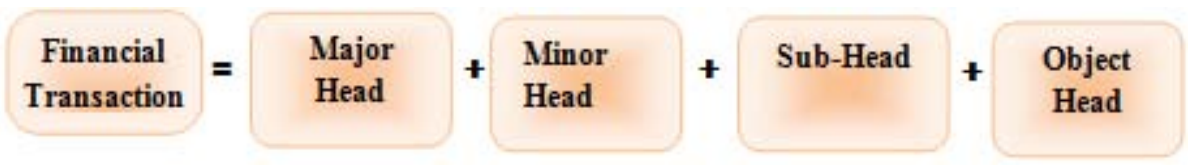

\section{Major Head}

Major Heads are classified which is of a four digit which specially represent the function, which correspond to one of the (29) functions enumerated in the 11th Schedule of the Constitution are classified under 23 major heads. In addition to the 23 Major Heads three more Major Head as shown below has been opened to facilitate the PRIs to account their activities.
2049- Interest Payments

2071- Pension and Other Retirement Benefits and

2515- Panchayat Raj Programmes

One can identify the nature of transaction just see the starting digit of the (four-digit) code of the Major Head.

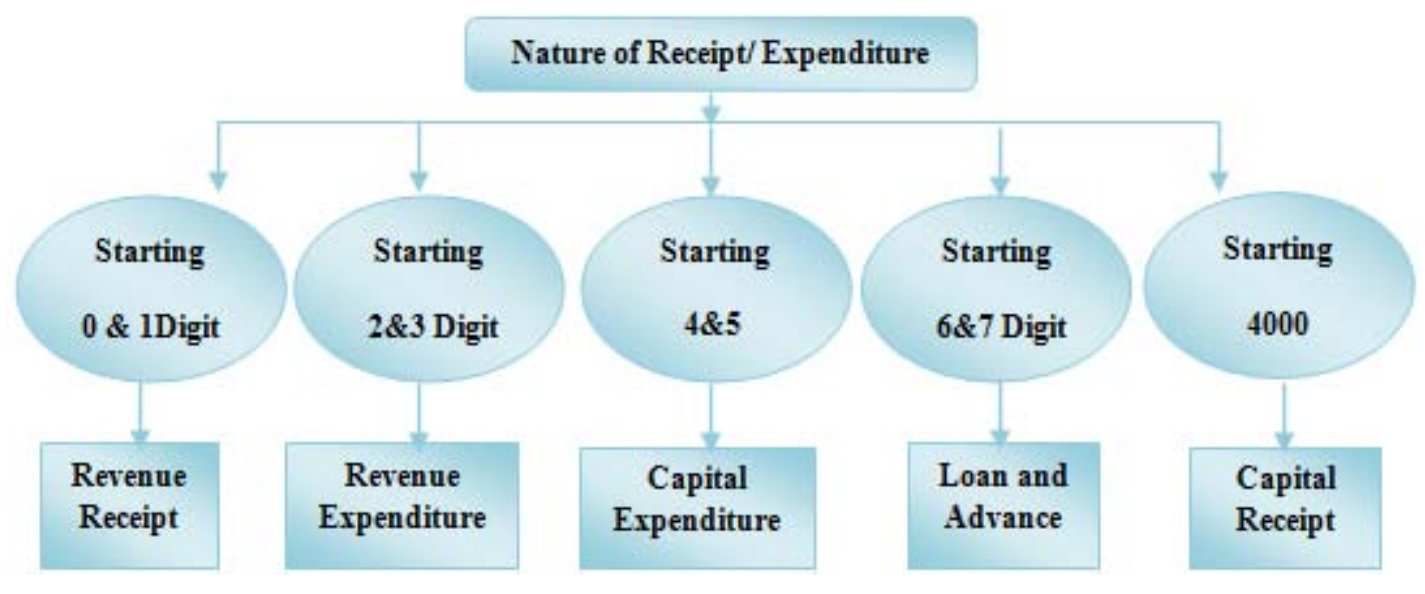

Volume 4 Issue 12, December 2015 


\section{International Journal of Science and Research (IJSR) \\ ISSN (Online): 2319-7064}

Index Copernicus Value (2013): 6.14 | Impact Factor (2014): 5.611

Additional Major Heads to record all transaction( Receipts and Payment/Disbursement) under Loan, Pension \& Provident Fund, Insurance and Pension Fund, Deposit and Advance and Civil Advance, depending upon the requirement

\begin{tabular}{|c|c|}
\hline Code & Account Head \\
\hline 7610 & Loan to Panchayat Employees \\
\hline 8009 & Provident Fund \\
\hline 8011 & Insurance and Pension Fund \\
\hline 8443 & Civil Deposit \\
\hline 8550 & Civil Advances \\
\hline 8658 & Suspense Account \\
\hline
\end{tabular}

\section{Minor Head}

The Minor Heads, with a three digit code, identify the programme undertaken to achieve the objectives of the functions. Illustration of the minor head is shown below.

\begin{tabular}{|c|c|c|}
\hline $\begin{array}{c}\text { Major } \\
\text { Head }\end{array}$ & Function & Minor Head \\
\hline 0028 & Taxes on & 101- Profession Tax \\
& $\begin{array}{c}\text { Profession, Trades } \\
\text { etc. }\end{array}$ & 103- Trade License Fees \\
\hline 0045 & Taxes on Duties and & 101 - Entertainment Tax \\
& Commodities & $102-$ Advertisement Tax \\
& & $104-$ Receipts under Other Acts \\
\hline 2202 & Education & 101 - Primary Education \\
& & 102 -Secondary Education \\
& & 103 -Adult Education \\
\hline
\end{tabular}

\section{Object Code}

For most commonly used items of expenditure a two-digit standardized object head (inputs) have been standardized. The object head under receipts head can be opened as per requirement.

\begin{tabular}{|c|c|c|c|c|c|}
\hline Code & Object Head & Code & Object Head & Code & Object Head \\
\hline $\mathbf{0 1}$ & Salaries & $\mathbf{1 0}$ & Audit Fee & $\mathbf{1 9}$ & Subsidies \\
\hline $\mathbf{0 2}$ & Wages & $\mathbf{1 1}$ & Printing & $\mathbf{2 0}$ & Share of taxes/duties \\
\hline $\mathbf{0 3}$ & Overtime Allowance & $\mathbf{1 2}$ & Other Administrative Expenses & $\mathbf{2 1}$ & Motor Vehicle/hiring charges \\
\hline $\mathbf{0 4}$ & Pensionary Charges & $\mathbf{1 3}$ & Supplies and Materials & $\mathbf{2 2}$ & Machinery and Equipment \\
\hline $\mathbf{0 5}$ & Honoraria & $\mathbf{1 4}$ & Petrol/Diesel & $\mathbf{2 3}$ & Major Works \\
\hline $\mathbf{0 6}$ & Medical Treatment & $\mathbf{1 5}$ & Advertising and Publicity & $\mathbf{2 4}$ & Write off/ losses \\
\hline $\mathbf{0 7}$ & Travel Expenses & $\mathbf{1 6}$ & Other Contractual Services & $\mathbf{2 5}$ & Deduct Recoveries \\
\hline $\mathbf{0 8}$ & Office Expenses & $\mathbf{1 7}$ & Grants-in-aid & $\mathbf{2 6}$ & Maintenance \\
\hline $\mathbf{0 9}$ & Rent, Rates and Taxes & $\mathbf{1 8}$ & Contribution & $\mathbf{8 0}$ & Other Expenditure \\
\hline
\end{tabular}

\section{Sub Head}

A two digit codification of the schemes has been done as under. In order to earmark the transactions under specific scheme, the codification of schemes was desirable.

\begin{tabular}{|c|c|c|c|}
\hline Code & Scheme Description & Code & Scheme Description \\
\hline 11 & $\begin{array}{c}\text { National Rural } \\
\text { Employment Guarantee } \\
\text { Scheme (NREGS) }\end{array}$ & 17 & Total Sanitation Campaign \\
\hline 12 & $\begin{array}{c}\text { Sampoorna Gramin Rozgar } \\
\text { Yojana (SGRY) }\end{array}$ & 18 & Mid Day Meal Scheme \\
\hline 13 & $\begin{array}{c}\text { Swaranjayanti Gram } \\
\text { Swarozgar Yojana(SGSY) }\end{array}$ & 19 & Sarva Shiksha Abhiyan \\
\hline 14 & $\begin{array}{c}\text { Indira Awas Yojana (IAY) } \\
\text { Alarana }\end{array}$ & 20 & $\begin{array}{c}\text { Pradhan Mantri Gram } \\
\text { Sadak Yojana (PMGSY) }\end{array}$ \\
\hline 15 & $\begin{array}{c}\text { National Rural Health } \\
\text { Mission (NRHM) }\end{array}$ & 21 & $\begin{array}{c}\text { Integrated Watershed } \\
\text { Management Programme }\end{array}$ \\
\hline 16 & $\begin{array}{c}\text { Accelerated Rural Water } \\
\text { Supply Programme } \\
\text { (ARWSP) }\end{array}$ & 22 & $\begin{array}{c}\text { Integrated Child } \\
\text { Development Services } \\
\text { (ICDS) }\end{array}$ \\
\hline
\end{tabular}

Example:

2210 Health and Sanitation (Major Head)

101 Primary Health Centre (Minor Head)

15 NHRM (Sub-Head)

02 Wages (Object Head)

\section{Registers Prescribed}

Under model accounting system (8) formats are now recommended. Maintenance of these Registers would eventually help in shifting over to Accrual System of Accounting.

\begin{tabular}{|c|l|c|}
\hline S. No. & Form No. & Book/Register \\
\hline 1 & Form-I & $\begin{array}{c}\text { Monthly/Annual Receipts and Payments } \\
\text { Account }\end{array}$ \\
\hline 2 & Form-II & Consolidated Abstract Register \\
\hline 3 & Form-III & $\begin{array}{c}\text { Reconciliation Statement with Bank and } \\
\text { Treasury }\end{array}$ \\
\hline 4 & Form-IV & Statement of Receivable and Payable \\
\hline 5 & Form-V & Register of Immovable Property \\
\hline 6 & Form-VI & Register of movable Property \\
\hline 7 & Form-VII & Inventory Register \\
\hline 8 & Form-VIII & Register of Demand, Collection and balance \\
\hline
\end{tabular}

\section{Conclusion}

As accounting is record of transaction which visualize the monetary situation of the Institution so as it important for every institution to know the financial situation in same manner Panchayati Raj Institutions are required to maintain their account, so for these institution Model Accounting System is introduced by C\&AG on the recommendation of Eleventh Finance Commission. Model Accounting System is based on the concept of Cash Book, The Accounts are to be kept in two parts, Part - I To record transactions of all receipts and expenditure relating to Panchayats Fund, Part II To record transactions relating to Provident Funds, Loans, Deposits and Advances in this account are classified in four different head viz. Major Head, Minor Head, Sub-Head and Object Head. Yet no work has be done on Model Accounting System in Research Field, this can be introduce in University Syllabus. Codification of Model Accounting System should be simplified so it can be easily followed in practice. 


\section{International Journal of Science and Research (IJSR) \\ ISSN (Online): 2319-7064}

Index Copernicus Value (2013): 6.14 | Impact Factor (2014): 5.611

\section{References}

[1] Model Accounting System,for Panchayat. C\& AG of India \& Ministry of Panchayati Raj, Govt. of India

[2] National Panchayat Accounting Manual Vol. I Accounting Systems \& Treatments (Draft Version) Developed by Infrastructure Professionals Enterprise (P) Ltd. New Delhi, India.

[3] Google. 